\title{
Flight behaviour of Ips typographus L. (Col., Scolytidae) in an environment without pheromones
}

\author{
Anne J. Franklin ${ }^{\mathrm{a}, \mathrm{b}, \mathrm{c}, \mathrm{d}^{*}}$, Jean-Claude Grégoire ${ }^{\mathrm{b}, \mathrm{d}}$ \\ ${ }^{a}$ Centre Luxembourgeois de l'U.L.B, 19, rue de la Fontaine, B-6870 Saint-Hubert, Belgium \\ ${ }^{b}$ Laboratoire de biologie animale et cellulaire, université Libre de Bruxelles, CP 160/12, 50 av. F.D. Roosevelt, \\ B-1050 Brussels, Belgium \\ ${ }^{\mathrm{C}}$ Fonds pour la formation à la recherche dans l'industrie et l'agriculture \\ ${ }^{\mathrm{d}}$ Fonds national de la recherche scientifique
}

(Received 4 January 1999 ; accepted 9 June 1999)

\begin{abstract}
A mark-recapture experiment with Ips typographus (Coleoptera: Scolytidae) was carried out on a 1-ha experimental plot in a healthy spruce stand in Belgium. Recapture of the released beetles was carried out using 96 unbaited standing live trap trees distributed homogeneously over the experimental plot. Less than $0.3 \%$ of the marked beetles were recaptured during three replicates of the experiment. When a pheromone lure was added to one of the trap trees in a fourth replicate, the recapture rate rose to nearly $6 \%$. Implications for the beetles' dispersal are discussed. Moreover, the take-off rates were found to be strongly correlated to weather conditions at emergence: correlations between take-off percentages and the number of sunshine hours per day $(r=0.75)$, the average daytime relative humidity $(\mathrm{r}=-0.75)$ and the cloud cover index at noon $(\mathrm{r}=-0.63)$ were found to be highly significant $(P<0.005)$. $\odot 1999$ Éditions scientifiques et médicales Elsevier SAS.
\end{abstract}

Ips typographus / Scolytidae / bark beetle / dispersal / flight

Résumé - Comportement de vol d'Ips typographus dans un environnement sans phéromones. Une expérience de lâchers-recaptures avec Ips typographus (Coleoptera: Scolytidae) a été menée sur une parcelle expérimentale d'un hectare, au sein d'un massif d'épicéas sans attaques de scolytes en Belgique. Afin d'étudier la dispersion à courte distance des scolytes, 96 arbres pièges sur pied, sans attractifs, ont été répartis de manière homogène sur la parcelle expérimentale. Moins de $0.3 \%$ des scolytes marqués ont été recapturés lors de trois répétitions de l'expérience. Lorsqu'une source de phéromones a été ajoutée au dispositif lors d'une quatrième répétition, le taux de recaptures s'est élevé à près de 6\%. Les implications pour la dispersion des scolytes sont discutées. De plus, une bonne corrélation entre le taux d'envol des scolytes et les conditions météorologiques a été observée lors des différentes expériences. Les corrélations les plus fortes correspondent à celles entre le taux d'envol et le nombre d'heures d'ensoleillement par jour $(\mathrm{r}=0.75$, $P<0.005)$, l'humidité relative moyenne en journée $(\mathrm{r}=-0.75, P<0.005)$ et l'indice de couverture nuageuse à midi $(\mathrm{r}=-0.63$, $P<0.005)$. (C) 1999 Éditions scientifiques et médicales Elsevier SAS.

Ips typographus / Scolytidae / scolyte / dispersion / vol

\section{Introduction}

The process of colonisation of host trees by bark beetles is a complex behavioural sequence which starts with flight initiation, leads to dispersal, selection and concentration on a host tree and ends with establishment on the selected tree [34]. Dispersal is an essential step in the process as it enables the beetles to colonise new breed-

* Correspondence and reprints afrankli@ulb.ac.be 
ing sites. However, the search for suitable sites can be arduous as the host trees are often hidden among a vast number of non-host trees or unsuitable host material.

The dispersal of Ips typographus has been extensively studied, both in the laboratory and in the field. Newly attacked trees can be found close to previously colonised ones, indicating that flights might be very short $[2,10]$. On the other hand, I. typographus has been found more than $40 \mathrm{~km}$ away from spruce forests [23] and has been shown to fly up to several hours in laboratory studies [11].

Common methods for studying bark beetle dispersal are mark-recapture experiments and mass trapping, which are mostly carried out by means of pheromone traps (e.g. $[4,9,15,26,31])$. These experiments are, however, inadequate for the study of the initial phases of dispersal, when bark beetles disperse in search of new breeding material. During those early stages, in most situations, the beetles would have to fly in an environment without pheromones before encountering attraction sources, whether primary or secondary. Appropriate recapture and tracking techniques therefore need to be used, with all the difficulties arising from the follow-up of beetles without the support of artificial lures.

The aim of this project was to study the first phases of the dispersal process, namely behaviour at and shortly after take-off. This was carried out by investigating short-distance flights of emerging $I$. typographus $(0-50$ $m$ ) in a forest hosting no known natural or artificial spruce bark beetle pheromone sources in an area of several hectares around the experimental plot. The following questions were addressed. 1) What proportion of insects will stay close to the emergence site and explore nearby trees? Do beetles land soon after take-off or do they need some flight exercise before landing? 2) Do weather conditions influence take-off rates and play a role in initial dispersal?

\section{Materials and methods}

\subsection{Study area}

Experiments were carried out in 1997 under non-outbreak conditions in the Bertrix Forest District (southern Belgium). The 1-ha experimental plot was located in a planted, healthy, homogeneous 70-year-old Norway Spruce (Picea abies L.) stand of 7 ha situated at an altitude of $435 \mathrm{~m}$, on slightly sloping ground oriented to the west. The stand density approximated 400 trees/ha, with an average tree DBH $(1.5 \mathrm{~m}$ high $)$ of $41 \pm 6 \mathrm{~cm}$ and a site index of $30.7 \mathrm{~m}$. No beetle attack had been recorded in the study area since 1995 .

\subsection{Beetles}

Beetles were collected from infested trees in spring (overwintering beetles) and summer (spring/summer generation) never more than $10 \mathrm{~km}$ away from the experimental plot. In spring, the bark containing the beetles was stored in a cool $\left(10-13{ }^{\circ} \mathrm{C}\right)$ and dark room for a maximum of 3 weeks before use. In summer, logs with immature beetles were left to mature in the field, then the bark was removed when the beetles reached the adult stage. In each case, the infested bark slabs were placed under emergence tents [20] at the centre of the experimental plot, just before the flight began.

\subsection{Release-recapture}

Beetles were released between noon and 6 p.m., when the temperature rose above $18-20^{\circ} \mathrm{C}$, the flight threshold for I. typographus [1,3]. Emerging beetles were collected and sprayed with a water suspension of fluorescent powder as soon as they appeared in the collection jars. From earlier mark-recapture experiments [2, 7, 25], it was assumed that the marking process and the powder did not significantly affect the flight behaviour of marked beetles. As soon as they were marked, the beetles were placed on the release platform $-\mathrm{a} 1-\mathrm{m}^{2}$ wooden board placed on a post $1.5 \mathrm{~m}$ above ground level at the centre of the experimental plot - in a rectangular plastic container and allowed to dry out and fly away. To prevent any beetle from walking away, the sides of the plastic container were treated with Fluon ${ }^{\circledR}$ (Fluon GP1, De Monchy Int., Rotterdam). Beetles that did not fly were excluded from the experiment, but their number was recorded. Freshly emerging beetles were used each day. Beetles emerging between two experimental periods were not used in the experiments.

Ninety-six unbaited, live, standing trap trees were selected as uniformly as possible throughout the experimental plot (figure 1). Each trap tree was fitted with two collecting funnels [24] $50 \mathrm{~cm}$ above ground, one facing the centre of the plot and the other facing the opposite direction. Each trap tree was sprayed with a pyrethryoid insecticide (Ripcord 40: $400 \mathrm{~g}$ cypermethrin/L, S.A. Belgian Shell, $25 \mathrm{~mL} / 10 \mathrm{~L}$ water) up to $6 \mathrm{~m}$ high [14] on the sides carrying the collecting funnels. The proportion of trees fitted with collectors amounted to approximately $25 \%$ of all trees present in the plot. The treatment was repeated twice during the flight season, in April and July. Previous experiments show that the insecticide treatment does not act as a repellent to the beetles [24]. 


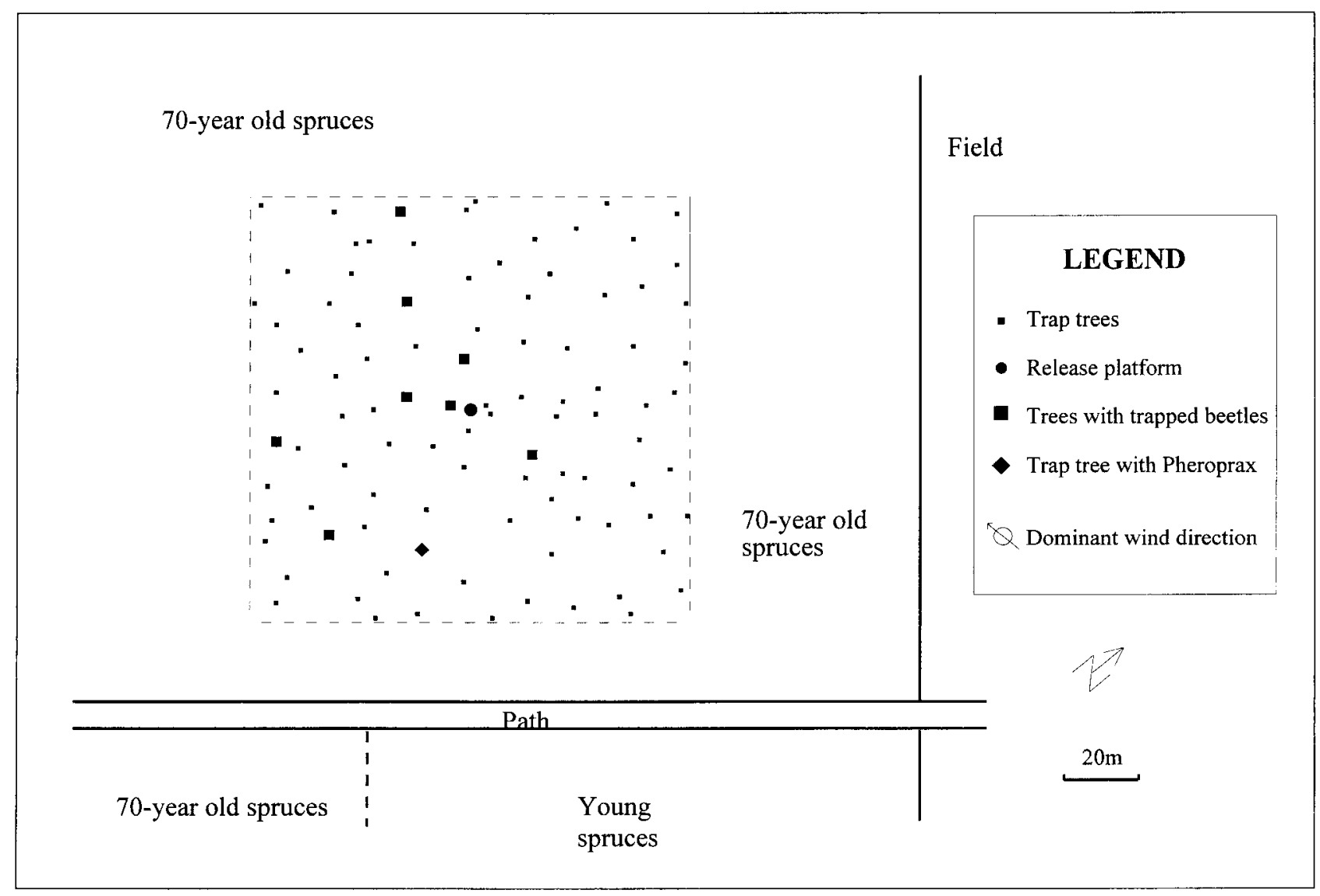

Figure 1. Presentation of the 1-ha experimental plot, located in a healthy, homogeneous 70 -year-old spruce stand. Trap tree density amounted to approximately one in four trees present in the stand.

Four sets of releases were carried out throughout the season. The first two took place during the first flight period (May 1997) and consisted of overwintering beetles while the last two were made up of summer generation beetles (August 1997). The first three mark-recapture experiments studied dispersal in an environment without pheromones, as none of the trap trees were equipped with attractive material. In order to compare beetle behaviour in the presence and in the absence of a pheromone lure, the fourth experiment introduced a modification in the experimental set-up: one of the trap trees was baited with a Pheroprax ${ }^{\circledR}$ dispenser. The pheromone-baited trap tree was situated $35 \mathrm{~m}$ away from the release platform and was chosen randomly within the trap trees located at a distance of $30-50 \mathrm{~m}$ from the platform (figure 1).

As it has been shown that most beetles are recaptured within the first few days of their release $[15,20,25,33$,
36 , the collecting funnels were emptied $24 \mathrm{~h}$ after the release, except for experiment 4 , when they were emptied on the same day; a second collection took place 2 or 3 days later, in order to check whether more beetles had been caught in the traps. The number of marked and unmarked beetles caught in the traps was counted, with confirmation of identification of marked individuals under an ultraviolet lamp.

\subsection{Weather data}

Weather data were provided from a meteorological station located in Saint-Hubert, about $20 \mathrm{~km}$ north of the experimental plot. In order to establish a relationship between these data and local climatic conditions, temperature and air humidity were monitored at the release site during experiment 3 . A cloud-cover index was also esti- 
mated according to a scale in octas [21], 0 octas $(0 / 8)$ corresponding to the absence of clouds and 8 octas $(8 / 8)$ to a heavy overcast sky with a full cloud cover. Significant relationships were obtained for maximum day temperatures, average relative humidity and cloudcover index at noon but not for minimum air temperatures at night (table I). Climatic conditions were considered to be relatively similar at the two sites and the data from the meteorological station were subsequently used throughout the experimental period.

\subsection{Statistical analysis}

Significance of the linear regressions between weather data at the experimental site and at the meteorological station, and between weather data and bark beetle takeoff (tables $I$ and $V$ ) was tested by analysis of variance [35]. Trap catches were analysed with the Fisher exact probability test [30].

\section{Results}

\subsection{Beetle dispersal}

A total of 11765 I. typographus were marked, 8612 of which took off and initiated flight $(74 \%$ of the marked beetles). The number of recaptured beetles was low, amounting to only 41 individuals (table II). All the beetles were caught within the first $24 \mathrm{~h}$ of their release. Only eight beetles were caught during the first three experiments $(0-0.25 \%)$ while the 33 remaining ones $(5.7 \%)$ were recaptured during experiment 4 in the collecting funnels of the trap tree baited with Pheroprax ${ }^{\circledR}$. Differences in trap catches with and without pheromones are statistically significant (Fisher exact probability test; $P<0.01$ ). In experiment 4,41 unmarked beetles were captured in addition to the 33 marked ones, while no unmarked beetles were caught during experiments 1-3 (table II).

Most of the marked beetles were captured in the collectors facing the release platform (table III): $75 \%$ during experiments $1-3$, when only two collectors were fitted per tree and $55 \%$ during experiment 4 , when four collectors were fitted on the baited trap tree.

None of the unbaited trees in the experimental plot were attacked during the experiments, neither was the Pheroprax ${ }^{\circledR}$ baited trap tree above the treated area.

\subsection{Take-off behaviour}

The proportion of flying and non-flying $I$. typographus varied considerably from one release day to another

Table I. Relationship between weather data at Bertrix (experimental site) and Saint Hubert (weather station) during experiment 3 (5-12 August $1997 ; n=8$ ).

\begin{tabular}{lccc}
\hline Parameter & Relationship & $\mathrm{R}^{2}$ & $P$ \\
\hline Maximum day temperature $\left({ }^{\circ} \mathrm{C}\right)$ & $\operatorname{Tmax}_{\text {on site }}=1.06 * \operatorname{Tmax}_{\text {station }}$ & 0.91 & $<0.01$ \\
Minimum night temperature $\left({ }^{\circ} \mathrm{C}\right)$ & $\mathrm{Tmin}_{\text {on site }}=0.85 * \mathrm{Tm}_{\text {station }}$ & 0.14 & $\mathrm{NS}$ \\
Average relative humidity $(\%)$ & $\mathrm{RH}_{\text {on site }}=1.00 * \mathrm{RH}_{\text {station }}$ & 0.81 & $<0.05$ \\
Cloud-cover index at noon (octas) & $\mathrm{CI}_{\text {on site }}=0.95 * \mathrm{CI}_{\text {station }}^{*}$ & 0.91 & $<0.0001$ \\
\hline
\end{tabular}

$\$$ Regression based on meteorological data from experiments $1-4$ (May-August $1997 ; n=13$ ).

Table II. Number of marked $I$. typographus released and recaptured during the various experiments at Bertrix, 1997. Experiments 1-3 were carried out without pheromones, while a Pheroprax ${ }^{\circledR}$ baited trap tree was included in experiment 4 . Releases during experiment 2 were carried on 15, 17 and 19 May.

\begin{tabular}{|c|c|c|c|c|c|}
\hline Experiment & $\begin{array}{l}\text { Release } \\
\text { period }\end{array}$ & $\begin{array}{l}\text { No. marked } \\
\text { and released }\end{array}$ & $\begin{array}{l}\text { No. marked } \\
\text { in catch }\end{array}$ & $\begin{array}{c}\% \\
\text { recaptured }\end{array}$ & $\begin{array}{c}\text { Total trap } \\
\text { catches }\end{array}$ \\
\hline 1 & May 2-3 & 3478 & 0 & 0 & 0 \\
\hline 3 & August 5-12 & 2540 & 3 & 0.12 & 3 \\
\hline 4 & August $25 /$ September 1 & 574 & 33 & 5.75 & 74 \\
\hline Total $1-3$ & & 8038 & 8 & & 8 \\
\hline
\end{tabular}


Table III. Percentage of I. typographus caught in the trap tree collectors in relation to their position towards the release platform. Unbaited trap trees were fitted with two collectors each, the Pheroprax ${ }^{\circledR}$ baited trap tree was fitted with four collectors.

\begin{tabular}{lccc}
\hline & Experiments 1-3 & \multicolumn{2}{c}{ Experiment 4 } \\
& Marked beetles & Marked beetles & Unmarked beetles \\
\hline No. of beetles & 8 & 33 & 41 \\
Collectors facing the release platform & $75 \%$ & $55 \%$ & $55 \%$ \\
Collectors opposite of the release platform & $25 \%$ & $9 \%$ & $20 \%$ \\
Additional side collectors & - & $36 \%$ & $25 \%$ \\
\hline
\end{tabular}

Table IV. Average percentages of flying I. typographus per day of release and average daily weather conditions at the weather station ( \pm standard deviation) during the various experiments at Bertrix, 1997. Releases during experiment 2 were carried on 15,17 and 19 May.

\begin{tabular}{|c|c|c|c|c|c|c|c|c|c|}
\hline Experiment & $\begin{array}{c}\text { Release } \\
\text { period }\end{array}$ & $\begin{array}{l}\text { No. } \\
\text { days }\end{array}$ & $\begin{array}{l}\text { Average } \\
\% \text { flyers }\end{array}$ & $\begin{array}{l}\text { Average day } \\
\text { temperature } \\
\left({ }^{\circ} \mathrm{C}\right)\end{array}$ & $\begin{array}{l}\text { Sunshine } \\
\text { (hours/d) }\end{array}$ & $\begin{array}{c}\text { Relative } \\
\text { humidity } \\
(\%)\end{array}$ & $\begin{array}{l}\text { Wind } \\
\text { speed } \\
(\mathrm{m} / \mathrm{s})\end{array}$ & $\begin{array}{l}\text { Dominant } \\
\text { wind } \\
\text { directions }\end{array}$ & $\begin{array}{l}\text { Cloud- } \\
\text { cover index } \\
\text { (octas) }\end{array}$ \\
\hline 2 & May 15-19 & 3 & $48 \pm 17$ & $15.8 \pm 2.5$ & $8.7 \pm 1.0$ & $71 \pm 7$ & $3.7 \pm 1.1$ & E, SE & $5 \pm 2$ \\
\hline 3 & August $5-12$ & 8 & $83 \pm 15$ & $21.2 \pm 0.8$ & $10.7 \pm 3.5$ & $60 \pm 10$ & $3.5 \pm 0.9$ & $\mathrm{E}, \mathrm{ESE}$ & $3 \pm 2$ \\
\hline Augu & st $25 /$ September 1 & 2 & $84 \pm 17$ & $20.4 \pm 3.9$ & $9.7 \pm 4.0$ & $69 \pm 7$ & $3.5 \pm 0.6$ & $\mathrm{~S}, \mathrm{SW}$ & $2 \pm 1$ \\
\hline
\end{tabular}

$\ddagger$ Results for the two release days are pooled as non-flying beetles on 2 May were included in the experiment on the next day: on 2 May, beetles were still taking off at 6 p.m., when the experiment was stopped. The non-flyers were kept, on this occasion only, on the experimental plot for the night and released again on the next day.

even though threshold temperatures for flight were reached (table $I V$ ). The daily proportion of flyers ranged from 32 to $93 \%$ depending on day of release, which is similar to data from Wollerman [33] for Scolytus multistriatus, Salom and McLean [26] for Trypodendron lineatum and Jactel [16] for I. sexdentatus but much lower than the minimum of $90 \%$ take-off obtained by Botterweg [4] and Weslien and Lindelöw [32] for $I$. typographus.

These highly fluctuating daily proportions of flyers led us to investigate of the influence of environmental factors on the take-off of I. typographus. A positive correlation $(P<0.005)$ was observed between the percentage of take-offs per day and the number of sunshine hours and negative correlations were found between take-off and average relative humidity and cloud-cover index $(P<0.005)$. Take-off rates increased significantly with higher minimum night temperatures or average daily temperatures. There were no significant relationships between take-off rates and maximum temperatures or average day wind speeds (table $V$ ).

\section{Discussion}

\subsection{Beetle dispersal}

Less than $0.3 \%$ of the released beetles were recaptured during the "pheromone-free" experiments, which suggests that they rapidly flew away from the experimental plot. These observations could mean that $I$. typographus needs some flight exercise prior to landing, a hypothesis put forward for several bark beetle species $[6,13,15,28]$. On the other hand, as I. typographus usually breeds in a non-resisting substrate such as windfallen or stressed trees, which were absent from the experimental plot, the released beetles could also have been forced to fly away in search of adequate breeding material.

A few of the marked I. typographus did, however, land near the release platform, which indicates that some beetles are able to land soon after take-off. These beetles could well have been poor flyers, but as Ips species are able to make several short consecutive flights [11, 17], they might also have resumed flight after a short rest on the tree. The beetles could also have been hitting the 
Table V. Results of linear regressions between take-off percentages and weather conditions at the meteorological station on each day of release.

\begin{tabular}{lccc}
\hline & $\mathrm{R}$ & $\mathrm{R}^{2}$ & $P$ \\
\hline Avg. Temperature $\left({ }^{\circ} \mathrm{C}\right)$ & 0.58 & 0.33 & $<0.05$ \\
Max. Day temperature $\left({ }^{\circ} \mathrm{C}\right)$ & 0.38 & 0.15 & $\mathrm{NS}$ \\
Min. Night temperature $\left({ }^{\circ} \mathrm{C}\right)$ & 0.61 & 0.37 & $<0.05$ \\
Hours of sunshine/day $(\mathrm{h})$ & 0.75 & 0.56 & $<0.005$ \\
Avg. Wind speed $(\mathrm{m} / \mathrm{s})$ & -0.17 & 0.03 & $\mathrm{NS}$ \\
Avg. Relative humidity $(\%)$ & -0.75 & 0.57 & $<0.005$ \\
Cloud-cover index (octas) & -0.63 & 0.40 & $<0.005$
\end{tabular}

NS $=$ non-significant results at the $P=5 \%$ level. $n=13$ for each regression (no. of release days).

trees by chance but as it was observed that beetles were deliberately avoiding the trees closest to the release platform, we assume that all beetles were landing beetles.

During the fourth experiment, nearly $6 \%$ of the released beetles were caught on the trap tree baited with Pheroprax ${ }^{\circledR}$, which is comparable to recapture rates observed in other mark-recapture experiments $[4,32,36]$ considering that only one pheromone trap tree was present in the spruce stand. Some of the marked beetles were caught shortly after their take-off, as the first catches on the trap tree occurred less than 5 min after the initial release of the beetles. It seems unlikely that those early catches corresponded to beetles that had first flown away from the experimental plot then returned, attracted by the pheromone source. In addition, table III indicates that marked beetles were mostly captured in collectors facing the point of release, both in experiments 1-3 and in experiment 4.

Recaptures during experiment 4 show that at least a fraction of the emerging spruce bark beetle population is able to respond immediately to a source of attraction - in this case, secondary attraction - and therefore does not need to perform a preliminary flight as evoked earlier. These results are in agreement with those obtained by Lindelöw and Weslien [20], who observed emerging $I$. typographus respond to nearby pheromone traps without the need for an extended period of flight exercise.

\subsection{Take-off behaviour}

The percentage of flying I. typographus varied considerably from day to day. As experimental conditions were kept as identical as possible in all experiments, we assume that part of the variation observed in take-off rates was due to changing weather conditions.
Long periods of sunshine and low relative humidity enhanced take-off and initial dispersal as demonstrated by the percentages given in table $I V$ and by the regressions shown in table $V$. As these two parameters are highly correlated $\left(\mathrm{r}_{\text {sunshine hours }-\mathrm{RH}}=-0.837, P<0.001\right)$, their individual influence on take-off cannot be assessed from our experiment. However, it was observed that when sunlight fell on the experimental platform beetles rose quickly towards the sky while fewer beetles took off when there was no sun. This is consistent with laboratory observations from Shepherd [29] and Choudhury and Kennedy [6] who showed that initial scolytid flight was dominated by a phototactic response.

We did not find any evidence of a relationship between wind speed and take-off of marked beetles although it was shown for $S$. multistriatus that during periods of high wind velocities, the beetles did not fly off but waited for brief decreases in wind speed before launching themselves into the air [19, 22].

Shifts in wind speed and direction occurred frequently but it was observed that after the initial movement towards light patches, beetles tended to fly downwind. Moreover, most of the recaptured I. typographus in experiments 1-3 were caught in traps downwind from the release platform: as winds came predominantly from the east (table $V$ ), five out of eight recaptured beetles $(62.5 \%)$ were caught in traps to the west of the experimental plot, three $(37.5 \%)$ to the south, one $(12.5 \%)$ to the east and none to the north of the plot (figure 1 ). These observations are in agreement with data from Gara [12], who showed that in field experiments the take-off flight of I. paraconfusus occurred in all directions but predominantly with the wind, when winds higher than 0.8 to $1.0 \mathrm{~m} / \mathrm{s}$ prevailed. Similar observations were reported for I. typographus and T. lineatum [4, 26, 27].

\section{Conclusions}

The simplest model of dispersal, passive diffusion, supposes that the environment is constant and homogeneous, that all individuals are identical and that they move randomly [18]. If the beetles landed randomly on trees, we would observe a gradual dilution in the number of catches per tree as a function of distance from the emergence site. Although only eight beetles were recaptured, this tendency seems to be reflected in our data $\left(\mathrm{y}=2.02 \mathrm{x}^{-1.00}\right.$ with $\mathrm{y}=$ no. beetles/tree and $\mathrm{x}=$ distance in meters; $R^{2}=0.66$; regression non-significant as based on three points only). A higher proportion of recaptures occurred to the west of the experimental plot but this directional effect is not necessarily incompatible with passive diffusion: a dilution effect can be observed with- 
in the preferential flight direction. If more beetles had been recaptured, passive diffusion would probably have been observed in all directions, although on different scales.

The total number of beetles landing close to the emergence site can be estimated for the 1-ha experimental plot. Only one tree out of four was fitted with collecting funnels. On those trap trees, the two collecting funnels covered about half the tree's surface as a collecting funnel is about $30 \mathrm{~cm}$ wide and the average tree DBH was $41 \mathrm{~cm}$. The 6-m-high insecticide treatment probably allowed the capture of most landing beetles, as Duelli et al. [8] observed that less than $5 \%$ of $I$. typographus flew over $10 \mathrm{~m}$ high. It would therefore be reasonable to think, assuming random landing, that the total number of marked I. typographus that landed was eight times higher than the observed number. This is probably a conservative estimate as some of the landing beetles do not fall in the collecting funnels, being carried away by the wind [24]. With an observed recapture rate of $0.25 \%$ (table II), the actual landing rate in the stand would then approach $2 \%$. Starting from a population of 2000 beetles, this would mean that about 40 beetles could have landed within 1 ha of the emergence site.

Experiments 1-3 show that even in the absence of a pheromone source, some l. typographus individuals land on trees near their release point, while experiment 4 shows that a much larger fraction of the released population lands close to the take-off platform when a source of attraction is present. One hypothesis could be that, in both cases, the landing beetles correspond to the same population of poor flyers that do not disperse far from their emergence site: they would respond to a nearby attraction source when present but would land on nearby trees when they do not meet any pheromone plumes.

Under natural conditions, while in presence of trees susceptible to beetle attack, the combination of these two behaviours can easily lead to the creation of new infestation spots near the emergence site. According to current knowledge, once one or a few pioneer individuals locate a susceptible tree, attack is initiated and pheromones are produced [5]. This production of aggregation pheromones allows the recruitment of beetles that would not otherwise have found the tree. The process is gradual: each landing beetle produces pheromones that will increase the tree's attractiveness by a small amount. This increase will in turn increase the rate at which the beetles arrive on the tree, therefore again increasing the tree's radius of attractiveness and so on, creating a local population.

Mass attack close to a previously attacked site could therefore result from the initial colonisation of susceptible trees by a small number of poor flyers, while the bet- ter flyers would explore potential attack locations farther away. The beetles responding to pheromones produced by the pioneer beetles could be coming from distant infestation spots or could be better flyers that emerged close by, flew away for some time and came back after becoming receptive to the pheromone plume.

Acknowledgements: We thank P. Maréchal, D. Emond and J.M. Lamotte for their support in the field. Funding for this work was provided by a F.R.I.A. Ph.D. research grant to Anne Franklin. J.-C. Grégoire thanks the Fonds national de la recherche scientifique for financial support.

\section{References}

[1] Abgrall J.-F., Juvy B., Incidence de la température sur le développement de la première génération annuelle du typographe, Ips typographus $L$. Cemagref - Division de la protection phytosanitaire de la forêt, Grenoble, 1992.

[2] Anderbrant O., Dispersal of re-emerged spruce bark beetles, Ips typographus (Coleoptera, Scolytidae): a mark-recapture experiment, Z. Ang. Entomol. 99 (1) (1985) 21-25.

[3] Annila E., Influence of temperature upon the development and voltinism of Ips typographus L. (Coleoptera, Scolytidae), Ann. Zool. Fennici 6 (1969) 161-207.

[4] Botterweg P.F., Dispersal and flight behaviour of the spruce bark beetle Ips typographus in relation to sex, size and fat content, Z. Ang. Entomol. 94 (5) (1982) 466-489.

[5] Byers J.A., An encounter rate model of bark beetle populations searching at random for susceptible host trees, Ecol. Modelling. 91 (1996) 57-66.

[6] Choudhury J.H., Kennedy J.S., Light versus pheromonebearing wind in the control of flight direction by bark beetles, Scolytus multistriatus, Physiol. Entomol. 5 (1980) 207-214.

[7] Dubois G., Migration de Ips typographus L. (Coleoptera: Scolytidae) en forêt d'épicéa commun (Picea abies Karst.), mémoire de fin d'études, université Libre de Bruxelles, Brussels, 1992.

[8] Duelli P., Studer M., Näf, W., Der Borkenkäferflug auberhalb des Waldes, J. Appl. Entomol. 102 (1986) 139-148.

[9] Duelli P., Zahradnik P., Knizek M., Kalinova B., Migration in spruce bark beetles (Ips typographus) and the efficiency of pheromone traps, J. Appl. Entomol. 121(6) (1997) 297-304.

[10] Forsse E., Flight duration of eleven species of bark beetles (Scolytidae) and observations of aerial height distribution. Migration in bark beetles with special reference to the spruce bark beetle Ips typographus, Doctoral dissertation, Sveriges Lantbruksuniversitet, Uppsala, 1989.

[11] Forsse E., Solbreck C., Migration in the bark beetle Ips typographus $\mathrm{L}$.: duration, timing and height of flight, $\mathrm{Z}$. Ang. Entomol. 100 (1985) 47-57. 
[12] Gara R.I., Studies on the flight behavior of Ips confusus (Lec.) (Coleoptera: Scolytidae) in response to attractive material, Contrib. Boyce Thompson Inst. 22(1) (1963) 51-66.

[13] Graham K., Release by flight exercise of a chemotropic response from photopositive domination in a scolytid beetle, Nature 184 (1959) 283-284.

[14] Grégoire J.-C., De Proft M., Protection des forêts contre l'Ips typographus, Fiche technique no. 6, Ministère de la Région Wallonne - DGRNE, Jambes (Namur), 1996.

[15] Jactel H., Dispersal and flight behaviour of Ips sexdentatus (Coleoptera: Scolytidae) in pine forest, Ann. Sci. For. 48 (1991) 417-428.

[16] Jactel H., Individual variability of the flight potential of Ips sexdentatus Boern. (Coleoptera: Scolytidae) in relation to day of emergence, sex, size and lipid content, Can. Entomol. 125(5) (1993) 919-930.

[17] Jactel H., Gaillard J., A preliminary study of the dispersal potential of Ips sexdentatus Boer (Coleoptera: Scolytidae) with an automatically recording flying mill, J. Appl. Entomol. 112 (1991) 138-145.

[18] Kareiva P.M., Local movement in herbivorous insects: applying a passive diffusion model to mark-recapture field experiments, Oecologia. 57 (1983) 322-327.

[19] Lanier G.N., Silverstein R.M., Peacock J.W., Attractant pheromone of the European elm bark beetle (Scolytus multistriatus): isolation, identification synthesis, and utilisation studies, in: Anderson J.F., Kaya H.K. (Ed.), Perspectives in Forest Entomology, Academic Press, New York, 1976, pp. 149-175.

[20] Lindelöw A., Weslien J., Sex-specific emergence of Ips typographus L. (Coleoptera: Scolytidae) and flight behavior in response to pheromone sources following hibernation, Can. Entomol. 118 (1986) 59-67.

[21] Malacorps M. (Ed.), Observations climatologiques, Parties I et II, août 1997, Bulletin mensuel de l'I.R.M, Institut Royal Météorologique de Belgique, Bruxelles, 1997.

[22] Meyer H.J., Norris D.M., A mathematical relation to describe the influence of wind on the initial flight dispersal of Scolytus multistriatus (Coleoptera: Scolytidae), Ann. Entomol. Soc. Am. 66(3) (1973) 505-508.

[23] Nilssen A.C., Long-range aerial dispersal of bark beetles and bark weevils (Coleoptera, Scolytidae and
Curculionidae) in Northern Finland, Ann. Entomol. Fenn. 50 (1984) 37-42.

[24] Raty L., Drumont A., De Windt N., Grégoire J.-C., Mass trapping of the spruce bark beetle Ips typographus L.: trap or trap trees?, For. Ecol. Manage. 78 (1995) 191-205.

[25] Salom S.M., McLean J.A., Influence of wind on the spring flight of Trypodendron lineatum in second growth coniferous forests Can. Entomol. 121 (1989) 109-120.

[26] Salom S.M., McLean J.A., Dispersal of Trypodendron lineatum (Olivier) within a valley setting, Can. Entomol. 122 (1990) 43-58.

[27] Salom S.M., McLean J.A., Environmental influences on dispersal of Trypodendron lineatum (Coleoptera: Scolytidae), Environ. Entomol. 20 (1991) 565-576.

[28] Schlyter F., Löfqvist J., Response of walking spruce bark beetles Ips typographus to pheromone from different attack phases, Entomol. Exp. Appl. 41 (1986) 219-230.

[29] Shepherd R.F., Factors influencing the orientation and rates of activity of Dendroctonus ponderosae Hopkins (Coleoptera: Scolytidae), Can. Entomol. 98 (1966) 507-518.

[30] Siegel S., Nonparametric Statistics for the Behavioral Sciences, McGraw-Hill Kogakusha LDT, Tokyo, 1956.

[31] Turchin P., Thoeny W.T., Quantifying dispersal of southern pine beetles with mark-recapture experiments and a diffusion model, Ecol. Appl. 3 (1993) 187-198.

[32] Weslien J., Lindelöw A., Recapture of marked spruce bark beetles (Ips typographus) in pheromone traps using areawide mass trapping, Can. J. For. Res. 20 (1990) 1786-1790.

[33] Wollerman E.H., Attraction of European elm bark beetles, Scolytus multistriatus, to pheromone-baited traps, J. Chem. Ecol. 5(5) (1979) 781-793.

[34] Wood D.L., The role of pheromones, kairomones and allomones in the host selection and colonisation behaviour of bark beetles, Annu. Rev. Entomol. 27 (1982) 411-446.

[35] Zar J.H., Biostatistical Analysis, 3rd ed., Prentice Hall International Ltd, London, 1996.

[36] Zumr V., Dispersal of the spruce bark beetle Ips typographus (L.) (Coleoptera, Scolytidae) in spruce woods, J. Appl. Entomol. 114 (1992) 348-352. 